\title{
ANTIBODIES ANTI-SACCHAROMYCES CEREVISIAE (ASCA) DO NOT DIFFERENTIATE CROHN'S DISEASE FROM CELIAC DISEASE
}

\author{
Lorete Maria da Silva KOTZE' ${ }^{1}$, Renato Mitsunori NISIHARA ${ }^{2}$, Shirley Ramos da Rosa UTIYAMA², \\ Paulo Gustavo KOTZE ${ }^{1}$, Petra Mirella THEISS ${ }^{1}$ and Márcia OLANDOSKI ${ }^{3}$
}

\begin{abstract}
Context - Anti-Saccharomyces cerevisiae antibodies (ASCA), considered serologic markers for Crohn's disease, were described in patients with celiac disease, disappearing after a gluten-free diet. Objectives - Evaluation of ASCA positivity in patients with Crohn's disease and celiac disease in relation to healthy individuals. Methods - A total of 145 individuals were studied: 36 with Crohn's disease and 52 with celiac disease, that fulfilled the diagnostic criteria for both affections, and 57 healthy individuals for control. The celiac patients were divided as follow: group CeD I at diagnosis $(n=34)$, group CeD II with gluten-free diet compliance $(n=13)$ and group CeD III with transgressions to the diet $(\mathrm{n}=5)$. ASCA IgA and IgG were determined by ELISA. Results - With statistical significance, ASCA IgA were positive in Crohn's disease, celiac disease at diagnosis and celiac disease with diet transgressions; ASCA IgG in Crohn's disease and in all groups with celiac disease. Conclusions - The detection of ASCA in patients with celiac disease allows to suggest that ASCA is not a specific marker for Crohn's disease, but was associated with the inflammation of the small intestine. The increased levels of positive ASCA may be due to genetic factors and increased intestinal permeability.
\end{abstract}

HEADINGS - Saccharomyces cerevisiae. Crohn disease. Celiac disease. Diet, gluten-free.

\section{INTRODUCTION}

Crohn's disease $(\mathrm{CD})$ is a chronic inflammatory bowel disorder of uncertain etiology which clinical course is characterized by relapsing and remitting chronic intestinal inflammation. The way in which environmental factors modify the expression of genes in susceptible individuals and modulate the effector function of the intestinal immune system is not yet well known. Antibodies to bake yeast and brewer's yeast (anti-Saccharomyces cerevisiae or ASCA) directed against cell wall oligomannosides epitopes have been proposed as serological marker for Crohn's disease (CD) with $60 \%$ of sensitivity and $80 \%$ of specificity ${ }^{(8)}$. In a Brazilian study, ASCA were positive in $80 \%$ of 40 patients with $\mathrm{CD}^{(22)}$. In CD ASCA seemed to have most significant association with small bowel disease, fibrostenosis, internal perforations and small bowel surgery ${ }^{(15,19)}$. However, the cause of ASCA positivity is still unknown and some authors have considered antibody formation as a consequence of increased mucosal permeability ${ }^{(11)}$. These changes are also found in 10\%-20\% of first-degree relatives of patients with $\mathrm{CD}^{(11,12)}$. ASCA are known to be positive in $0 \%-5 \%$ of healthy controls ${ }^{(8,20)}$.
Celiac disease $(\mathrm{CeD})$ is an immune-mediated enteropathy that is precipitated by the ingestion of gluten in genetically susceptible individuals ${ }^{(10)}$. The diagnosis includes positivity for serological tests as antiendomysium $(\operatorname{IgA~EmA})^{(27)}$ and/or anti-tissue transglutaminase (IgA anti-tTG) antibodies $^{(6)}$, and histological changes in small bowel mucosa ${ }^{(28)}$. The treatment with a gluten-free $\operatorname{diet}(\mathrm{GFD})$ result in healing of the mucosa changes, improvement of the malabsorptive state and reversal of the majority effects of the affection, including disappearance of the autoantibodies in the sera ${ }^{(10)}$. There are several studies demonstrating increased permeability of the gut mucosa in $\mathrm{CeD}$ by sugar absorption tests ${ }^{(25,26)}$ and the presence of food allergens. These changes also can disappear after a GFD. Probably the increased intestinal permeability may be related to constitutional factors in susceptible individuals and may detect latent $\mathrm{CeD}^{(7,12)}$.

Currently, there are reports of the presence of ASCA in the sera of patients with $\mathrm{CeD}$ at diagnosis and disappearing after a GFD, suggesting that ASCA can be a sensitive marker of intestinal mucosa integrity ${ }^{(5,9,23)}$.

In the differential diagnosis of intestinal disorders, the presence of autoantibodies in the sera can be helpful in the investigation of patients with unexplained complaints. In this context, the aims of the present study

Prêmio da Federação Brasileira de Gastroenterologia como o melhor trabalho de Gastroenterologia na VIII Semana Brasileira do Aparelho Digestivo, Brasília, DF, Brasil, 2008. This manuscript has not any potential conflicts of interest regarding specific financial interests (personal or institutional).

1 Hospital Cajuru, Pontifícia Universidade Católica do Paraná; ${ }^{2}$ Laboratório de Imunopatologia Molecular, Hospital de Clínicas, Universidade Federal do Paraná Departamento de Estatística, Pontifícia Universidade Católica do Paraná, Curitiba, PR, Brazil.

Correspondence: Prof. Lorete Maria da Silva Kotze - Rua Bruno Filgueira, 369 - cj. 1205 - 80240-220 - Curitiba, PR, Brazil. E-mail: loretekotze@hotmail.com 
were to evaluate the frequency of ASCA in patients with CD and $\mathrm{CeD}$ (at diagnosis and in a GFD), comparing the results with the data of healthy controls of the same geographic area.

\section{METHODS}

\section{Controls and patients}

The patients were studied at the Gastroenterology and Coloproctology Services, Cajuru Hospital, Pontifical Catholic University of Paraná, Curitiba city, State of Paraná, South Brazil. The study was approved by the Ethical Committee of the Institutions involved in the research.

Demographic data of the studied groups are showed in Table 1. Fifty-seven healthy individuals, 38 female $(66.7 \%)$ and 19 male (33.3\%), mean age 38.9 years (range 14 to 67 years) were enrolled as controls. Thirty-six patients with $\mathrm{CD}, 63.9 \%$ female, $36.1 \%$ male, mean age 42.9 years (range 16 to 83 years) were evaluated. Fifty-two patients previously diagnosed as having $\mathrm{CeD}, 38(73 \%)$ female and $14(27 \%)$ male, mean age 38.1 years (range 16 to 68 years) were divided as follow: 34 at diagnosis (Group CeD I) and 18 in a GFD, 13 with strict compliance to the diet (Group CeD II) and 5 that admitted transgressions (Group CeD III).

TABLE 1 - Demographic data of the controls and studied patients

\begin{tabular}{lccc}
\hline Group & Female $\%$ & Male $\%$ & Mean age (years) \\
\hline Controls $(\mathrm{n}=57)$ & 66.7 & 33.3 & $38.9(14-67)$ \\
CD $(\mathrm{n}=36)$ & 63.9 & 36.1 & $42.9(16-83)$ \\
CeD I $(\mathrm{n}=34)$ & 73.5 & 26.5 & $40.1(19-65)$ \\
CeD II $(\mathrm{n}=13)$ & 76.9 & 23.1 & $35.4(16-68)$ \\
CeD III $(\mathrm{n}=5)$ & 60.0 & 40.0 & $38.8(30-56)$ \\
\hline
\end{tabular}

$\mathrm{CD}=$ Crohn's disease; $\mathrm{CeD}$ I = celiacs at diagnosis; $\mathrm{CeD}$ II = celiacs adherent to a GFD;

$\mathrm{CeD}$ III $=$ celiacs with transgressions to a GFD

\section{Methods}

The serum samples of all the studied individuals, stored at $-80^{\circ} \mathrm{C}$, were submitted to antibodies evaluations in the Laboratory of Immunopathology, Clinical Hospital, Federal University of Paraná. The diagnosis of $\mathrm{CeD}$ was based on $\operatorname{IgA}$ antiendomysium (EmA) and IgA anti-tissue transglutaminase (anti-tTG) serum positivity plus histological findings of the intestinal biopsies ${ }^{(18,28)}$. An accurate dietetic interview was used to register data related to the current diet of the celiac patients. The patients with $\mathrm{CD}$ were diagnosed based on accepted clinical, endoscopic and radiological criteria supported by histopathology ${ }^{(19,20,21)}$. ASCA IgA and IgG were quantitated using a standard calibrated enzyme linked immunosorbent assay (ELISA) commercially kits and performed according to the manufacturer's instructions (QUANTA Lite ${ }^{\mathrm{TM}}$, INOVA, USA ${ }^{\circledR}$ ). ASCA IgA and IgG cut off values defining seropositivity were $20 \mathrm{U} / \mathrm{mL}$.

\section{Statistics}

Results are presented as the absolute number and percentage of patients that are positive for ASCAs. Differences between variables were evaluated by Fisher's exact test: $P$ values $<0.05$ were considered statistically significant.

\section{RESULTS}

All the controls, patients with $\mathrm{CD}$ and patients with $\mathrm{CeD}$ adherent to a GFD (group CeD II) were negative for IgA EmA and IgA anti-tTG; celiacs at diagnosis (group $\mathrm{CeD}$ I) and patients with no compliance to a GFD (group CeD III) were positive for both autoantibodies. The positivity of ASCA IgA and IgG for all the groups were summarized in Table 2. The statistical analysis is demonstrated in Table 3.

TABLE 2. Percentage of ASCA positivity in the studied groups

\begin{tabular}{lccc}
\hline Groups & $\begin{array}{c}\text { ASCA } \\
\text { IgA }\end{array}$ & $\begin{array}{c}\text { ASCA } \\
\text { IgG }\end{array}$ & $\begin{array}{c}\text { ASCA } \\
\text { IgA and IgG }\end{array}$ \\
\hline Controls $(\mathrm{n}=57)$ & 5.2 & 1.7 & 0.0 \\
CD $(\mathrm{n}=36)$ & 36.1 & 44.4 & 27.8 \\
CeD I $(\mathrm{n}=34)$ & 61.7 & 88.2 & 55.8 \\
CeD II $(\mathrm{n}=13)$ & 0.0 & 53.8 & 0.0 \\
CeD III $(\mathrm{n}=5)$ & 40.0 & 60.0 & 0.0 \\
\hline
\end{tabular}

$\mathrm{CD}=$ Crohn's disease; $\mathrm{CeD} \mathrm{I}=$ celiacs at diagnosis;

$\mathrm{CeD}$ II = celiacs adherent to a GFD; CeD III = celiacs with transgressions to a GFD

TABLE 3. Statistical analysis of ASCA positivity in the studied groups *

\begin{tabular}{lccc}
\hline Groups & ASCA IgA & ASCA IgG & ASCA IgA and IgG \\
\hline CD x Control & $<0.001$ & $<0.001$ & $<0.001$ \\
\hline CD x CeD I & 0.055 & $<0.001$ & 0.149 \\
CD x CeD II & 0.011 & 0.747 & 0.011 \\
CD x CeD III & 0.996 & 0.649 & 0.160 \\
\hline CeD I x Control & $<0.001$ & $<0.001$ & $<0.001$ \\
CeD II x Control & 1 & $<0.001$ & - \\
CeD III x Control & 0.048 & 0.001 & - \\
CeD I x CeD II & $<0.001$ & 0.017 & 0.001 \\
CeD I x CeD III & 0.631 & 0.161 & 0.047 \\
CeD II x CeD III & 0.065 & 1 & - \\
\hline
\end{tabular}

*Fisher's exact test $(P<0.05)$. In blot the data with statistical significance

$\mathrm{CD}=$ Crohn's disease; $\mathrm{CeD}$ I = celiacs at diagnosis; $\mathrm{CeD}$ II = celiacs adherent to a GFD

CeD III = celiacs with transgressions to a GFD

\section{DISCUSSION}

The demographic data showed that both $\mathrm{CD}$ and $\mathrm{CeD}$ had an young adult female preponderance, as demonstrated by several authors in different countries ${ }^{(2,10)}$.

Both $\mathrm{CD}$ and $\mathrm{CeD}$ can have similar gastrointestinal presentation and are characterized by the presence of distinct serological autoantibodies. The results of the present study confirm that IgA EmA and IgA anti-tTG are the most sensitive serological markers for $\mathrm{CeD}$, being negative in the healthy controls, in the CD patients and in the celiac patients with compliance to a $\mathrm{GFD}^{(13)}$.

The high prevalence of ASCA in CeD was previously reported by Giafer et al. ${ }^{(8)}$, specifically ASCA IgG. Damoiseaux et al. ${ }^{(5)}$ reported positivity for ASCA IgA and/ or $\mathrm{IgG}$ in $30 \%$ of 37 patients with biopsy-confirmed $\mathrm{CeD}$, while Granito et al ${ }^{(9)}$ reported $59 \%$ of ASCA positivity when evaluated $105 \mathrm{CeD}$ patients (adults and children). In the present investigation, the positivity of ASCA was unexpectedly increased in patients with $\mathrm{CeD}$ at diagnosis, showing ASCA IgA in $61.7 \%, \operatorname{IgG}$ in $88.2 \%$ and both $\operatorname{IgA}$ and $\mathrm{IgG}$ in $55.8 \%$, with statistical significance in relation to controls and patients with CD (Table 3). These values 
are higher than the data obtained by the cited authors. Mallant-Hente et al. ${ }^{(17)}$ reported $18 \%$ of ASCA positivity in 83 children and $61 \%$ in 28 adults with $\mathrm{CeD}$ at diagnosis, similarly to our results. The higher levels of ASCA observed at diagnosis of adults $\mathrm{CeD}$ patients probably may be related to the fact that they had been exposed to gluten for longer and therefore had more long-lasting damage ${ }^{(1,24)}$

The level of the ASCA also has been helpful in monitoring celiac patients for compliance to the GFD. Mallant-Hent et al. ${ }^{(17)}$ reported disappearance of ASCA in children $(1 \%)$ and a decreased in the adults $(29 \%)$ in GFD. In children the disappearance of ASCA positivity was more pronounced and this can be explained by the well-known fact that gut permeability normalizes better in children than in adults. Granito et al ${ }^{(9)}$ reported that the disappearance of ASCA IgA $(93 \%)$ was more frequent than that of ASCA IgG (17\%) after GFD. In our study we also find no ASCA IgA and only ASCA IgG in the patients with diet compliance (Table 2). By other hand, in the patients with transgressions to the GFD, the ASCA IgA was positive in $40 \%$ and $\operatorname{IgG}$ in $60 \%$, confirming that this determination can help in monitoring the diet, in spite the low number of individuals evaluated (Table 2). $\operatorname{IgA}$ is known to be a mucosal immunoglobulin and therefore may recover faster than the more systemic $\mathrm{IgG}$ (immunological memory). The positivity and the levels of ASCA IgG in treated patients with $\mathrm{CeD}$ with compliance to the diet or that admitted transgressions, were similar. This suggest that the period of gluten exposure is only one of the determinants of the mucosal changes (individual or genetic factor?).

ASCA can be a marker used in the differentiation of inflammatory bowel diseases (IBD). According to Saibeni et al. ${ }^{(21)}$ in the differential diagnosis of IBD, double positivity for ASCA IgA and IgG identifies with certainty the presence of $\mathrm{CD}$, as demonstrated in our study: ASCA IgA has been positive in $36.1 \%$ of the patients, ASCA IgG in $44.1 \%$ and both in $27.8 \%$, with statistical significance in relation to controls (Tables 2 and 3 ).

The high positivity detected in $\mathrm{CeD}$ patients at diagnosis, in a GFD and with diet transgressions (Tables 2 and 3), emphasizes that ASCA do not allow differentiate DC from CeD. Similarly, Makharia et al. ${ }^{(16)}$ reported that ASCA do not differentiate $\mathrm{CD}$ from intestinal tuberculosis.

The protective function of the intestinal mucosa is called "permeability"(12). When the intestinal mucosal barrier is broken, with junctions-mediated barrier defects, an influx of luminal antigens may result in inflammation, even by chronically stimulating resident, with consequent recruitement of immunocompetent cells from the lamina propria $^{(3,7)}$. In patients with autoimmune diseases, like $\mathrm{CD}$, or in infectious disease, and in various other clinical conditions, ASCA can be positive. The presence of ASCA may reflect a shared permeability disorder, leading to the enhanced exposure to various antigens that, depending on the genetic background, may provoke various or multiple autoimmune disorders. ${ }^{(3,4,5,7,9,14)}$. The antibodies in the sera of the analysed ASCA positive cases proved a systemic immune response against Sacharomyces cerevisiae (generally accepted as not a pathogen) and suggested the end of the oral tolerance against the yeast's antigens ${ }^{(3)}$.

In conclusion, the results show that ASCA was found in patients with CeD and disappear after a GFD. So, it is presumed that ASCA positivity is not a specific marker for Crohn's disease but correlates with the (auto) immune inflammation of the small intestine.

Kotze LMS, Nisihara RM, Utiyama SRR, Kotze PG, Theiss PM, Olandoski M. Anticorpos anti-Saccharomyces cerevisiae não diferenciam doença de Crohn de doença celíaca. Arq Gastroenterol. 2010;47(3):242-5.

RESUMO - Racional - Anticorpos anti-Saccharomyces cerevisiae antibodies, considerados marcadores sorológicos para a doença de Crohn, foram descritos em pacientes com doença celíaca, desaparecendo após dieta isenta de glúten. Objetivos - Avaliação da positividade de anti-Saccharomyces cerevisiae antibodies em pacientes com doença de Crohn e doença celíaca, em relação a indivíduos sadios da mesma área geográfica. Métodos - Foram estudados 145 pacientes, 36 com doença de Crohn e 52 com doença celíaca que preencheram os critérios diagnósticos para ambas as afecções, e 57 indivíduos sadios para controle. Os pacientes celíacos foram divididos como segue: ao diagnóstico (grupo doença celíaca I: $\mathrm{n}=34$ ), obedientes à dieta isenta de glúten (grupo doença celíaca II: $\mathrm{n}=13$ ) e não-aderentes à dieta isenta de glúten (grupo doença celíaca III: $\mathrm{n}=5$ ). Anti-Saccharomyces cerevisiae antibodies IgA e IgG foram determinados por ELISA. Resultados - Anti-Saccharomyces cerevisiae antibodies IgA foi positivo na doença de Crohn, nos celíacos ao diagnóstico e nos transgressores à dieta, com significado estatístico. Anti-Saccharomyces cerevisiae antibodies IgG foi positivo na doença de Crohn e em todos os grupos de celíacos, com significado estatístico. Conclusões - A detecção de anti-Saccharomyces cerevisiae antibodies em pacientes com doença celíaca permite sugerir que o mesmo não seja marcador específico para a doença de Crohn, mas que esteja associado à inflamação do intestino delgado. A positividade de anti-Saccharomyces cerevisiae antibodies pode ser decorrente de fatores genéticos e aumento da permeabilidade intestinal.

HEADINGS - Saccharomyces cerevisiae. Doença de Crohn. Doença celíaca. Dieta livre de glúten. 


\section{REFERENCES}

1. Ashorn S, Raukola H, Välineva T, Ashorn M, Wei B, Braun J, Rantala I, Kaukinen K, Luukkaala T, Collin P, Mäki M, Iltanen S. Elevated anti-Saccharomyces cerevisiae, anti-I2 and anti-OmpW antibody levels in patients with suspicion of celiac disease. J Clin Immunol. 2008;28:486-94.

2. Bardella MT, Elli L, De Matteis S, Floriani I, Torri V, Piodi L. Autoimmune disorders in patients affected by celiac sprue and inflammatory bowel disease. Ann Med. 2009;41:139-43.

3. Barta Z, Csipõ I, Szabó GG, Szegedi G. Seroreactivity against Saccharomyces cerevisiae in patients with Crohn's disease and celiac disease. World J Gastroenterol. 2003;9:2308-12.

4. da Rosa Utiyama SR, da Silva Kotze LM, Nisihara RM, Carvalho RF, de Carvalho AG, de Sena MG, de Messias-Reason IJ. Spectrum of autoantibodies in celiac patients and relatives. Dig Dis Sci. 2001;46:2624-30.

5. Damoiseaux JG, Bouten B, Linders AM, Austen J, Roozendaal C, Russel MG, Forget PP, Tervaert JW. Diagnostic value of anti-Saccharomyces cerevisiae and antineutrophil cytoplasmic antibodies for inflammatory bowel disease: High prevalence in patients with celiac disease. J Clin Immunol. 2002;22:281-8.

6. Dieterich W, Ehnis T, Bauer M, Donner P, Volta U, Riecken EO, Schuppan D Identification of tissue transglutaminase as the autoantigen of celiac disease. Nat Med. 1997;3:797-801.

7. Fasano A, Shea-Donohue T. Mechanisms of disease: the role of intestinal barrier function in the pathogenesis of gastrointestinal autoimmune disease. Nat Clin Pract Gastroenterol Hepatol. 2005;2:416-22

8. Giaffer MH, Clark A, Holdsworth CD. Antibodies to Saccharomyces cerevisiae in patients with Crohn's disease and their possible pathogenic importance. Gut. 1992;33:1071-5.

9. Granito A, Zauli D, Muratori P, Muratori L, Grassi A, Bortolotti R, Petrolini N, Veronesi L, Gionchetti P, Bianchi FB, Volta U. Anti-Saccharomyces cerevisiae and perinuclear anti-neutrophil cytoplasmic antibodies in coeliac disease before and after gluten-free diet. Aliment Pharmacol Ther. 2005;21:881-7.

10. Green PHR, Cellier C. Celiac disease. N Engl J Med. 2007;357:1731-43.

11. Harrer M, Reinisch W, Dejaco C, Kratzer V, Gmeiner M, Miehsler W, Norman GL, Gangl A, Vogelsang H. Do high serum levels of anti-Saccharomyces cerevisiae antibodies result from a leakiness of the gut barrier in Crohn's disease? Eur J Gastroenterol Hepatol. 2003;15:1281-5.

12. Hollander D. Intestinal permeability, leaky gut, and intestinal disorders. Curr Gastroenterol Rep. 1999;1:410-6.

13. Kotze LM, Utiyama SR, Nisihara RM, Zeni MP, de Sena MG, Amarante HM Antiendomysium antibodies in Brazilian patients with celiac disease and their first-degree relatives. Arq Gastroenterol. 2001;38:94-103.

14. Kotze LM, Nisihara RM, da Rosa Utiyama SR, Piovezan GC, Kotze LR. Thyroid disorders in Brazilian patients with celiac disease. J Clin Gastroenterol. 2006:40:33-6.

15. Kotze LMS, Kotze PG. Doença de Crohn. In: Dani R, editor. Gastroenterologia essencial. $3^{\mathrm{a}}$. ed. Rio de Janeiro: Guanabara-Koogan;2006. p.332-57.
16. Makharia GK, Sachdev V, Gupta R, Lal S, Pandey RM. Anti-Saccharomyces cerevisiae antibody does not differentiate between Crohn's disease and intestinal tuberculosis. Dig Dis Sci. 2007;52:33-9.

17. Mallant-Hent RCh, Mary B, von Blomberg E, Yüksel Z, Wahab PJ, Gundy C, Meyer GA, Mulder CJ. Disappearance of anti-Saccharomyces cerevisiae antibodies in coeliac disease during a gluten-free diet. Eur J Gastroenterol Hepatol. 2006;18:75-8.

18. Marsh MN. Mucosal pathology in gluten sensitivity. In: Marsh MN. Coeliac disease. Oxford: Blackwell Scientific Publications; 1992. p.136-91.

19. Mow WS, Vasiliauskas EA, Lin YC, Fleshner PR, Papadakis KA, Taylor KD, Landers CJ, Abreu-Martin MT, Rotter JI, Yang H, Targan SR. Association of antibody responses to microbial antigens and complications of small bowel Crohn's disease. Gastroenterology. 2004;126:414-24.

20. Quinton JF, Sendid B, Reumaux D, Duthilleul P, Cortot A, Grandbastien B, Charrier G, Targan SR, Colombel JF, Poulain D. Anti-Saccharomyces cerevisiae mannan antibodies combined with antineutrophil cytoplasmic antoantibodies in inflammatory bowel disease: prevalence and diagnostic role. Gut. 1998;42:788-91.

21. Saibeni S, Folli C, de Franchis R, Borsi G, Vecchi M. Diagnostic role and clinica correlates of anti-Saccaromyces cerevisiae antibodies (ASCA) and anti-neutrophil cytoplasmic antibodies (p-ANCA) in Italian patients with inflammatory bowe diseases. Dig Liver Dis. 2003;35:862-8.

22. Steinwurz F, Scheinberg MA. Diagnóstico sorológico de doença inflamatória intestinal (ASCA e ANCA): avaliação de 70 casos. GED Gastroenterol Endosc Dig. 2001;20:41-2.

23. Toumi D, Mankaï A, Belhadj R, Ghedira-Besbes L, Jeddi M, Ghedira I. AntiSaccharomyces cerevisiae antibodies in coeliac disease. Scand J Gastroenterol. 2007:42:821-6.

24. van Elburg RM, Uil JJ, Mulder CJ, Heymans HS. Intestinal permeability in patients with coeliac disease and relatives of patients with coeliac disease. Gut 1993;34:354-7.

25. Vilela EG, Torres HO, Ferrari ML, Lima AS, Cunha AS. Gut permeability to lactulose and mannitol differs in treated Crohn's disease and celiac disease patients and healthy subjects. Braz J Med Biol Res. 2008;41:1105-9.

26. Vogelsang H, Wyatt J, Penner E, Lochs H. Screening for celiac disease in firstdegree relatives of patients with celiac disease by lactulose/mannitol test. Am J Gastroenterol. 1995;90:1838-42.

27. Volta U, Molinaro M, De Franceski I, Fratangelo D, Bianchi FB. IgA class antiendomysial antibodies on human umbilical cord tissue for celiac disease screening. Save both money and monkeys. Dig Dis Sci. 1995;40:1902-5.

28. World Gastroenterology Organisation Practice Guidelines. Celiac disease [on-line] World Gastroenterology Organisation; 2007. Available from: worldgastroenterology. org/celiac-disease.html 